\title{
Peningkatan Motivasi Belajar Siswa Menggunakan Macromedia Flash Sebagai Media Pembelajaran Interaktif
}

\author{
Hendra H. Dukalang \\ Ekonomi Syariah \\ IAIN Sultan Amai Gorontalo \\ hendra37.statistika@iaingorontalo.ac.id
}

\author{
Dini Lestari ${ }^{2}$ \\ Teknik Informatika \\ Universitas Negeri Gorontalo \\ dini_s1pti2013@mahasiswa.ung.ac.id
}

\begin{abstract}
Tujuan penelitian ini membuat media pembelajaran interaktif untuk meningkatkan motivasi belajar siswa dalam proses pembelajaran mata pelajaran jaringan dasar menggunakan macromedia flash. Penelitian ini menggunakan metode penelitian research and development $(R \& D)$. Populasi dalam penelitian ini adalah seluruh kelas $X$ jurusan teknik komputer jaringan tahun ajaran 2016/2017 di SMK Negeri 1 Batudaa. Pengambilan sampel dilakukan dengan teknik cluster sampling. Pengumpulan data dilakukan dengan cara angket, dan tes. Data yang telah diperoleh melalui test kemudian dianalisis secara deskriptif dan inferensial. Analisis deskriptif dilakukan melalui aktivitas siswa dalam pembelajaran serta data hasil belajar siswa yang dianalisis melalui tabel dengan mempresentasekan rata-rata. Sedangkan analisis inferensial dilakukan dengan menggunakan uji $t$ untuk mengetahui apakah terdapat perbedaan antara siswa yang menggunakan metode konvensional dan media pembelajaran interktif . Kemudian angket dianalisis menggunakan skala likert. Angket yang diberikan kepada guru sebagai ahli media sekaligus ahli materi mendapatkan presentase sebesar $80 \%$ sedangkan angket yang diberikan pada kelas ekperimen (prorses pembelajaran yang diberi perlakuan media pembelajaran) memperoleh presentase sebesar 79,09\%. Dan angket yang diberikan pada kelas kontrol (prorses pembelajaran konvensional) memperoleh presentase sebesar 52,00\%. Kemudian hasil belajar siswa pada kelas eksperimen mendapat presentase sebesar 47,92\% sedangakan yang tidak menggunakan alat bantu media pembelajaran mendapatkan presentase sebesar 39,99\%. Hasil penelitian ini menunjukkan bahwa hasil belajar siswa menggunakan alat bantu media pembelajaran lebih tinggi dibandingkan dengan hasil belajar siswa yang tanpa menggunakan alat bantu media pembelajaran.
\end{abstract}

Kata kunci : Media Pembelajaran Interaktif, Jaringan Dasar, dan Motivasi belajar

\section{PENDAHULUAN}

Mata pelajaran jaringan dasar merupakan salah satu mata pelajaran yang terdapat di Sekolah Menengah Kejuruan (SMK). Mata pelajaran ini banyak memberikan teori dibandingkan praktek sehingga kebanyakan siswa merasa bosan, ngantuk, dan jenuh pada saat proses pembelajaran berlangsung. Akibatnya siswa kurang menguasai mata pelajaran. Hal itu, dibuktikan dalam Toha (2014), ditemukan hasil belajar siswa tahun 2014 pada mata pelajaran jaringan dasar memiliki persentase ketuntasan hanya $38.88 \%$, sedangkan yang belum mencapai Kriteria Ketuntasan Minimal (KKM) atau belum tuntas sebanyak $61,12 \%$.

Dengan adanya variasi metode pembelajaran di kelas diharapkan ada peningkatan kualitas pembelajaran. Siswa menjadi termotivasi dalam belajar, daya kreativitas akan semakin meningkat, bersikap positif, bertambah pengetahuan dan keterampilan yang dikuasai. Sehingga dibutuhkan media pembelajaran yang interaktif. Maka dibuat suatu penelitian menggunakan metode penelitian pengembangan Research and Development $(R \& D)$ pada media pembelajaran interaktif dengan menambahkan fitur latihan-soal pada setiap pokok bahasan. Media pembelajaran ini dibuat khusus mata pelajaran jaringan dasar kelas X Jurusan Teknik Komputer Jaringan.

Penggunana media pembelajaran yang berbasis macromedia flash diharapkan dapat membantu guru dalam proses pembelajaran serta dapat meningkatkan motivasi dan hasil belajara pada siswa.

\section{KAJIAN LITERATUR}

a. Pengertian Media Pembelajaran

Menurut Utami (2012), Media pembelajaran adalah semua alat atau benda yang digunakan dalam kegiatan belajar mengajar dengan maksud untuk menyampaikan pesan pembelajaran dari sumber kepada penerima. Taharudin (2012), penggunaan media pembelajaran merupakan sebagai alat bantu mengajar yang baik harus bisa memberikan pemahaman lebih konkret kepada siswa, dengan cara pemahaman berupa penggabungan berbagai indera yang dimiliki oleh siswa, sehingga siswa lebih banyak menyerap materi yang disampaikan lewat media tersebut.

Media pembelajaran memiliki tiga fungsi utama , yaitu untuk memotivasi minat, memberikan informasi, dan memberikan petunjuk. Adapun damak positif menurut Kemp dan Dayton dalam pembelajaran adalah, penyampaian pembelajaran akan menjadi lebih baku, pembelajaran bias lebih menarik, pembelajaran menjadi lebih interaktif, hemat waktu, kualitas belajar meningkat, pembelajaran dapat dilakukan kapan dan dimanapun diinginka, dan meringankan beban guru, (Putri : 2017).

Dari penjelasan diatas dapat disimpulkan bahwa media pembelajaran merupakan suatu alat/media yang dapat 
menunjang proses belajar siswa untuk lebih memahami pesan yang disampaikan oleh guru. Sehingganya media pembelajaran memiliki peranan penting dalam pembelajaran. Beberapa manfaat menggunakan media pembelajaran yaitu sebagai berikut.

a. Pengajaran akan lebih menarik perhatian siswa sehingga dapat menumbuhkan motivasi belajar.

b. Metode mengajar akan semakin bervariasi, tidak hanya monoton.

c. Bahan pengajaran akan akan lebih jelas maknanya, sehingga akan lebih mudah dipahami oleh siswa

\section{b. Motivasi Belajar}

Motivasi dalam pembelajaran berarti suatu yang menggerakkan atau mendorong siswa untuk belajar yang berperan untuk menumbuhkan, memunculkan rasa senang, dan semangat untuk belajar, Hamalik (Aimmah : 2015). Motivasi dalam belajar adalah faktor yang terpenting dalam proses pembelajaran, karena hal tersebut merupakan keadaan yang mendorong siswa untuk melakukan belajar. Demikian pula dalam kegiatan belajar mengajar seorang anak didik akan berhasil jika mempunyai motivasi untuk belajar.

Pengertian motivasi menurut John W. Santrock dalam Taharudin (2012) adalah proses yang memberi semangat, arah, dan kegigihan perilaku. Artinya, perilaku yang termotivasi adalah perilaku yang penuh energy, terarah dan bertahan lama.

Dari uraian diatas dapat ditarik kesimpulan, motivasi belajar adalah suatu dorongan, dimana seseorang ingin bertingkah laku lebih baik atau mengalami perubahan tingkah laku dari sebelumnya untuk mencapai tujuan yang diinginkan. Dorongan tersebut, dapat dipengaruhi oleh dua faktor meliputi

a. Faktor internal yaitu yang berada dalam diri individu.

b. Faktor eksternal yaitu yang berada diluar dari individu, misalnya orang tua, lingkungan bahkan cara mengajar guru.

\section{c. Hasil Belajar}

Menurut Sudjana dalam Aimmah (2015) hasil belajar merupakan kemampuan yang dimiliki siswa setelah menerima pengalaman belajar. Hasbullah dalam bukunya yang berjudul belajar dan faktor-faktor yang mempengaruhi dikutip oleh Junianto (2014), "keberhasilan siswa dipengaruhi oleh beberapa hal antara lain kecerdasan, motivasi, konsentrasi, kesehatan jasmani, ambisi, tekad, lingkungan, cara belajar, perlengkapan, dan sifat-sifat negative yang dimiliki siswa.

Menurut Dimyati dan Mudjiono dalam Mutmainah (2014), ada beberapa faktor yang mempengaruhi siswa dalam mencaai hasil belajar yang baik, antara lain sikap terhadap belajar, motivasi belajar, konsentrasi belajar, mengolah bahan belajar, menyimpan perolehan hasil belajar, menggali hasil belajar yang tersimpan, kemampuan berprestasi, rasa percaya diri siswa, intelegensi, kebiasaan siswa, dan cita-cita siswa.
Dari urain diatas hasil belajar merupakan hasil dari kemampuan seseorang dalam suatu bidang untuk mencapainya serta dapat diukur dengan menggunakan tes. Keberhasilan siswa dalam mencapai hasil belajar dipengaruhi oleh beberapa faktor meliputi kecerdasan yang baik, pelajaran sesuai dengan bakat yang dimiki, ada minat dan perhatian yang tinggi dalam proses pembelajaran, motivasi yang baik dalam belajar, dan cara belajar yang baik.

\section{III.METODE PENELITIAN}

\section{A. Objek Penelitian}

Populasi dapat diartikan sekumpulan individu yang memiliki sifat dan karakteristik yang cenderung sama. Populasi dalam penelitian ini adalah semua siswa kelas $\mathrm{X}$ yang berada di SMK Negeri 1 Batudaa.

Jumlah sampel yang digunakan peneliti berjumlah 59 orang kelas X TKJ di SMK Negeri 1 Batudaa. Teknik pengambilan sampel menggunakan Cluster Sampling (Area Sampling). Cluster sampling cara pengambilan sampel yang berdasarkan pada cluster-cluster tertentu.

\section{B. Teknik Pengolahan Data}

Analisis statistik yang digunakan untuk menguji hipotesis penelitian, apakah motivasi belajar siswa yang menggunakan bantuan media pembelajaran lebih tinggi dibanding motivasi belajar siswa yang hanya menggunakan pembelajaran konvensional. Pengujian hipotesis penelitian ini adalah menggunakan uji t. Syarat uji t adalah kedua kelompok harus berasal dari populasi yang mempunyai varians homogen dan yang berdistribusi normal. Oleh sebab itu sebelum melakukan uji $\mathrm{t}$ perlu dilakukan pengujian homogenitas varians dan analisis normalitas.

\section{1) Uji Homogenitas Varians}

Pengujian homogenitas varians bertujuan untuk menguji kesamaan rata-rata dari beberapa varians. rumus yang digunakan adalah.

$$
F=\frac{\text { varians terbesar }}{\text { varians terkecil }}
$$

Hipotesis statistik yang akan di uji sebagai berikut :

$$
\begin{array}{ll}
\mathrm{H}_{\mathrm{o}} & : \sigma_{1}^{2}=\sigma_{2}^{2} \\
\mathrm{H}_{1} & : \sigma_{1}^{2} \neq \sigma_{2}^{2}
\end{array}
$$

Kriteria pengujiannya adalah terima $H_{0}$ jika $F_{\text {hitung }}<F_{\text {tabel }}$ dan tolak $H_{0}$ jika $F_{\text {hitung }} \geq F_{\text {tabel }}$. Atau $P-$ Value $<\alpha$ tolak $H_{0}$

\section{2) Uji Normalitas Data}

\section{Peningkatan Motivasi Belajar Siswa Menggunakan Macromedia Flash Sebagai Media Pembelajaran Interaktif}


Pengujian normalitas data bertujuan untuk mengetahui apakah data yang diperoleh dari hasil penelitian berdistrubusi normal atau tidak. Dalam penelitian ini uji normalitas yang digunakan adalah uji lilefors (Sudjana, 2005). Dimana hipotesis yang di uji adalah :

Hipotesis statistik yang akan di uji dinyatakan sebagai berikut

$\mathrm{H}_{0} \quad$ : Data berdistribusi normal

$\mathrm{H}_{1} \quad$ : Data tidak berdistribusi normal

Kriteria pengujiannya adalah terima $\mathrm{H}_{0}$ jika $L_{0} \leq L_{\text {tabel }}$ dan tolak $\mathrm{H}_{0}$ jika $L_{0}>L_{\text {tabel }}$ Pada taraf $\alpha$ yang dipilih.

\section{3) Pengujian Hipotesis}

Untuk melakukan uji hipotesis, digunakan uji t. sedangkan untuk membuat keputusan pengujian hipotesis digunakan uji satu pihak yakni dengan rumus:

$$
t=\frac{\bar{x}_{1}-\bar{x}_{2}}{s \sqrt{\frac{1}{n_{1}}+\frac{1}{n_{2}}}}
$$

Dengan

$$
s^{2}=\frac{\left(n_{1}-1\right) s_{1}^{2}+\left(n_{2}-1\right) s_{2}^{2}}{n_{1}+n_{2}-2}
$$

Keterangan;

$\mathrm{t}=$ Nilai hitung untuk uji $\mathrm{t}$

$\overline{x_{1}}=$ Nilai rata-rata kelas ekperimen

$\overline{x_{2}}=$ Nilai rata-rata kelas kontrol

$\mathrm{n}_{1} \quad$ = Jumlah anggota sampel kelas eksperimen

$\mathrm{n}_{2}=$ Jumlah anggota sampel kelas kontrol

$\mathrm{s}_{1}=$ Standar deviasi kelas eksperimen

$\mathrm{s}_{2} \quad=$ Standar deviasi kelas kontrol

$\mathrm{s}^{2} \quad=$ varians sampel

Hipotesis yang diuji adalah:

$\mathrm{H}_{\mathrm{o}} \quad$ = Tidak terdapat pengaruh media pembelajaran terhadap motivasi belajar siswa.

$\mathrm{H}_{\mathrm{a}} \quad=$ Terdapat pengaruh media pembelajaran terhadap motivasi belajar siswa.

Kriteria pengujiannya adalah terima $\mathrm{H}_{0}$ jika $t_{\text {hitung }} \leq t_{1-\alpha}$ dan tolak $\mathrm{H}_{0}$ jika $t_{\text {hitung }}>t_{1-\alpha}$. Dengan $\alpha=0,05$ dan derajat kebebasan $(\mathrm{dk})=\left(\mathrm{n}_{1}+\mathrm{n}_{2}-2\right)$.

\section{4) Menghitung Hasil Tanggapan}

Dalam menghitung hasil tanggapan (angket) digunakan rumus, sebagai berikut:

$$
\text { Rumus }=\mathrm{T} \times \mathrm{Pn}
$$

Keterangan :

$\mathrm{T}$ : Total jumlah responden yang memilih
Pn : Pilihan angka skor likert

\section{5) Interprestasi Skor Perhitungan}

Pencarian presentasi untuk mengetahui hasil tingkat kelayakan sebuah media pembelajaran oleh guru dan motivasi belajar siswa maka dapat menggunakan rumus berikut :.

Rumus index $\%=\frac{\text { total skor }}{Y} \times 100 \%$

\section{Persiapan penelitian}

a) Perijinan tempat penelitian.

b) Persiapan instrumen penelitian (silabus, RPP, angket, draf tes, dan draf desain media).

\section{Pelaksanaan Penelitian}

Adapun langkah-langkah penelitian yang diadaptasi oleh peneliti sebagai berikut:

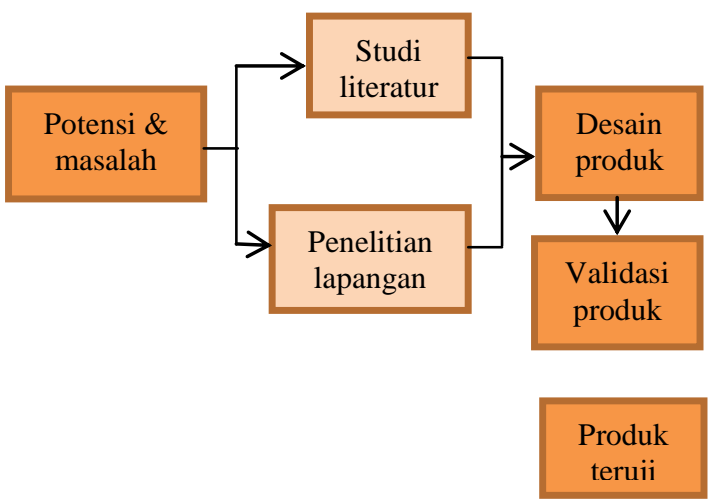

Gambar 1 Tahapan penelitian pengembangan R \& D (Sumber: Sugiyono)

\section{HASIL DAN PEMBAHASAN}

\section{$>$ Potensi dan Masalah}

\section{a. Studi literature}

Dari beberapa jurnal penelitian yang telah dibaca, media pembelajaran yang telah dibuat hanya fokus pada satu sub pokok bahasan saja. Selain itu, media pembelajran yang dibuat masih berpedoman pada KTSP.

\section{b. Penelitian lapangan}

$>$ Desain Produk

Pada tahap desain produk, peneliti membuat desain storyboard yang merupakan rancangan secara umum yang meliputi desain template, letak menu, tombol navigasi, dan materi yang akan disajikan. Berikut adalah tampilan media pembelajaran interaktif yang akan dihasilkan.

\section{Peningkatan Motivasi Belajar Siswa Menggunakan Macromedia Flash Sebagai Media Pembelajaran Interaktif}


a. Tampilan Intro dan Menu Utama

Pada saat intro deretan tampilan menu utama berjalan naik turun, kemudian akan muncul tulisan "halaman utama".

Tampilan menu utama merupakan halaman yang berisikan menu-menu yang ada pada media pembelajaran yang terdiri dari menu kompetensi dasar, menu materi, menu video, dan menu evaluasi.

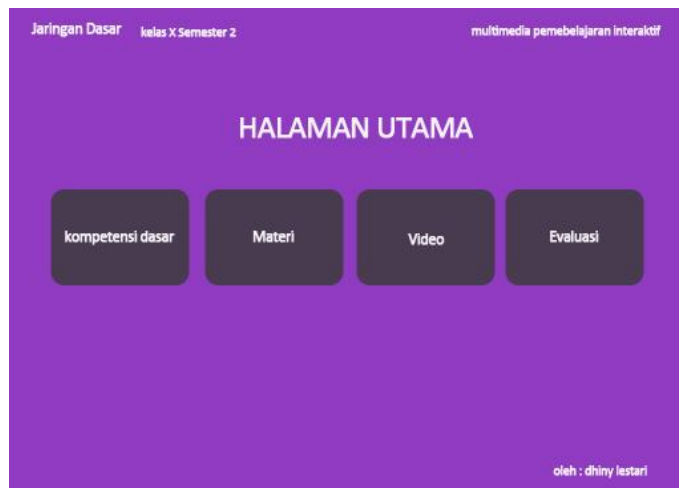

Gambar 2. Tampilan Menu Utama

b. Tampilan Kompetensi Dasar

Tampilan Kompetensi Dasar merupakan halaman yang menampilkan materi yang akan dibahas pada menu materi. Pada tampilan utama terdapat tombol untuk pindah menu awal. Menu Kompetesi dasar adalah salah satu implementasi dari tampilan menu utama.

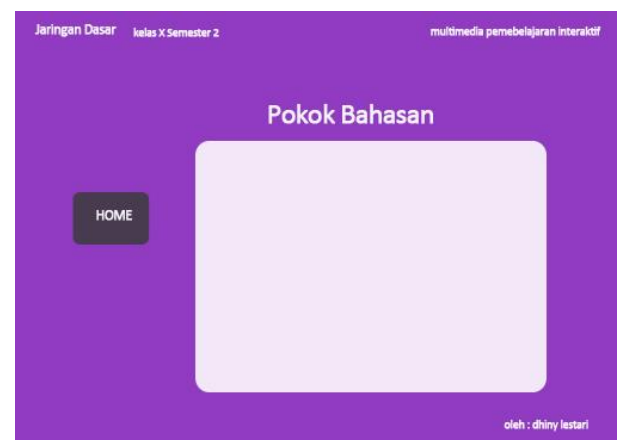

Gambar 3. Kompetensi Dasar

c. Tampilan Materi

Tampilan materi terdiri dari 5 pokok bahasan yang terdapat pada kelas $\mathrm{X}$ semester 2 sesuai dengan silabus kurikulum 2013 yang telah diminta dari guru mata pelajaran.

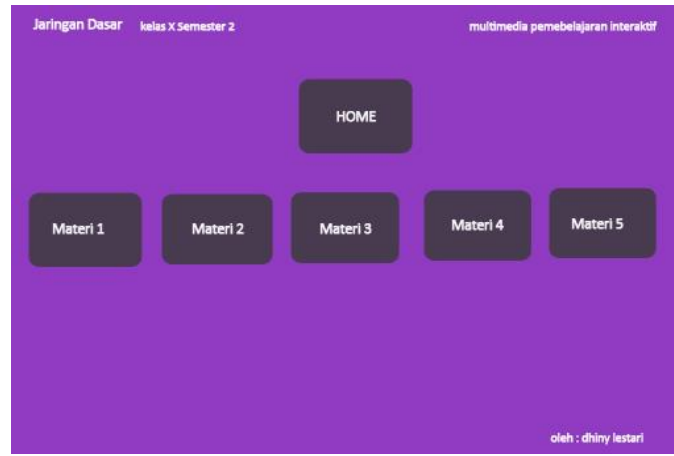

Gambar 4. Tampilan Halaman Materi

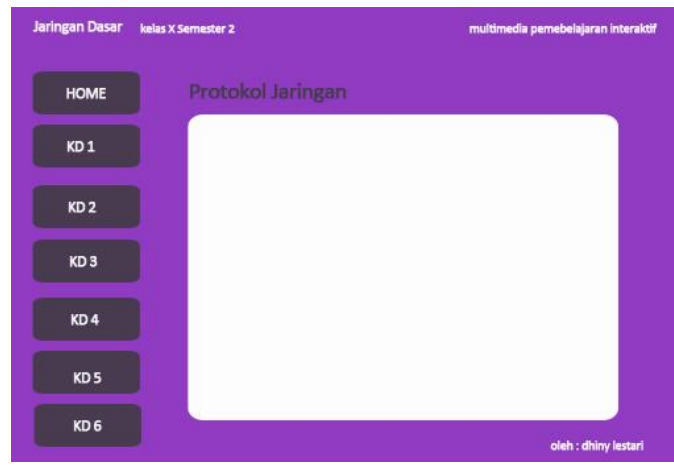

Gambar 5. Tampilan Isi Menu Materi

d. Tampilan Evaluasi

Tampilan evaluasi merupakan halaman yang menampilkan beberapa latihan soal yang digunakan untuk mengukur seberapa jauh pemahaman siswa mengenai materi yang telah diberikan.

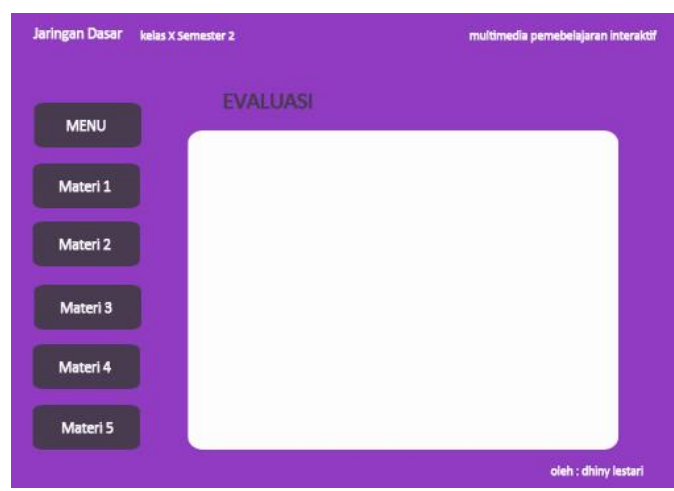

Gambar 6. Tampilan Halaman Evaluasi

\section{c. Deskripsi Data Penelitian}

Proses pembelajaran dengan menggunakan alat bantu media pembelajaran dapat meningkatkan motivasi belajar siswa dengan membandingkan hasil belajar siswa yang menggunakan media. Pembelajaran dan yang tidak menggunakan media pembelajaran.

Untuk presentasi hasil belajar bahwa,media pembelajaran interaktif dapat meningkatkan motovasi belajar siswa dengan

\section{Peningkatan Motivasi Belajar Siswa Menggunakan Macromedia Flash Sebagai Media Pembelajaran Interaktif}


ditandai hasil belajar siswa pada kelas eksperimen yang memenuhi KKM sebesar 47,92\% dibandingkan kelas kontrol sebesar $39,99 \%$.

Tabel 1. Presentasi Hasil Belajar Menggunakan Media

Pembelajaran Interaktif

\begin{tabular}{|c|c|c|c|c|c|}
\hline $\begin{array}{c}\text { Pokok } \\
\text { Bahasan }\end{array}$ & $\begin{array}{c}\text { Sumber } \\
\text { Data }\end{array}$ & $\mathbf{N}$ & Min & Max & Mean \\
\hline \multirow{2}{*}{$\begin{array}{l}\text { Protokol } \\
\text { Jaringan }\end{array}$} & $\begin{array}{c}\text { Kelas } \\
\text { Eksperimen }\end{array}$ & 29 & 64 & 100 & 79,52 \\
\hline & $\begin{array}{c}\text { Kelas } \\
\text { Kontrol }\end{array}$ & 30 & 55 & 91 & 72,10 \\
\hline \multirow{2}{*}{$\begin{array}{c}\text { Protokol } \\
\text { Pengalamatan }\end{array}$} & $\begin{array}{c}\text { Kelas } \\
\text { Eksperimen }\end{array}$ & 29 & 50 & 90 & 74,48 \\
\hline & $\begin{array}{c}\text { Kelas } \\
\text { Kontrol }\end{array}$ & 30 & 40 & 100 & 70,67 \\
\hline \multirow{2}{*}{$\begin{array}{c}\text { Perangkat } \\
\text { Keras Jaringan }\end{array}$} & $\begin{array}{c}\text { Kelas } \\
\text { Eksperimen }\end{array}$ & 29 & 60 & 100 & 79,31 \\
\hline & $\begin{array}{c}\text { Kelas } \\
\text { Kontrol }\end{array}$ & 30 & 60 & 100 & 77,33 \\
\hline \multirow{2}{*}{$\begin{array}{c}\text { Sistem Operasi } \\
\text { Jaringan }\end{array}$} & $\begin{array}{c}\text { Kelas } \\
\text { Eksperimen }\end{array}$ & 29 & 55 & 91 & 71,76 \\
\hline & $\begin{array}{c}\text { Kelas } \\
\text { Kontrol }\end{array}$ & 30 & 45 & 82 & 65,97 \\
\hline \multirow{2}{*}{$\begin{array}{c}\text { Pengembangan } \\
\text { Jaringan }\end{array}$} & $\begin{array}{c}\text { Kelas } \\
\text { Eksperimen }\end{array}$ & 29 & 55 & 91 & 74,24 \\
\hline & $\begin{array}{c}\text { Kelas } \\
\text { Kontrol }\end{array}$ & 30 & 55 & 91 & 72,70 \\
\hline
\end{tabular}

\section{d. Pegolahan Data Angket/ Kuesioner}

1) Angket Motivasi Belajar Siswa

Berdasarkan hasil penilaian siswa data angket motivasi belajar pada kelas eksperimen yang terdapat pada lampiran 9 diperoleh hasil perhitungan jawaban responden sebagai berikut :

Tabel 2. Hasil Angket Motivasi Kelas Eksperimen

\begin{tabular}{|c|c|c|c|}
\hline No & & T x Pn & Total \\
\hline 1 & $\begin{array}{c}\text { Responden yang } \\
\text { menjawab sangat setuju } \\
(5)\end{array}$ & $0 \times 5$ & 0 \\
\hline 2 & $\begin{array}{c}\text { Responden yang } \\
\text { menjawab setuju (4) }\end{array}$ & $21 \times 4$ & 84 \\
\hline 3 & $\begin{array}{c}\text { Responden yang } \\
\text { menjawab Ragu-ragu (3) }\end{array}$ & $1 \times 3$ & 3 \\
\hline 4 & $\begin{array}{c}\text { Responden yang } \\
\text { menjawab tidak setuju (2) }\end{array}$ & $0 \times 2$ & 0 \\
\hline 5 & $\begin{array}{c}\text { Responden yang } \\
\text { menjawab sangat tidak } \\
\text { setuju (1) }\end{array}$ & $0 \times 1$ & 0 \\
\hline \multicolumn{3}{|c|}{ Total } & $\mathbf{8 7}$ \\
\hline
\end{tabular}

$\mathbf{Y}=$ Skor tertinggi likert $\mathrm{x}$ jumlah responden $(5 \mathrm{x} 22)=110$

$\mathbf{X}=$ Skor terendah $\mathrm{x}$ jumlah responden $(1 \times 22)=22$.

Jadi, jika total responden terhadap media pembelajaran tersebut adalah hasil nilai yang dihasilkan dengan menggunakan rumus index \%. Maka penyelesaian akhir :

Rumus index $\%=\frac{87}{110} x 100 \%$

Rumus index $\%=79,09 \%$

Berdasarkan hasil diatas dan berpedoman pada tabel kriteria skala sikap maka diperoleh presentasi motivasi belajar siswa sebesar 79,09\% dan masuk dalam kriteria Baik.

Berdasarkan hasil penilaian siswa data angket motivasi belajar pada kelas eksperimen yang terdapat pada lampiran 10 diperoleh hasil perhitungan jawaban responden sebagai berikut.

Tabel 3. Angket Motivasi Kelas kontrol

\begin{tabular}{|c|c|c|c|}
\hline No & & T x Pn & Total \\
\hline 1 & $\begin{array}{c}\text { Responden yang } \\
\text { menjawab sangat setuju } \\
(5)\end{array}$ & $0 \times 5$ & 0 \\
\hline 2 & $\begin{array}{c}\text { Responden yang } \\
\text { menjawab setuju (4) }\end{array}$ & $0 \times 4$ & 0 \\
\hline 3 & $\begin{array}{c}\text { Responden yang } \\
\text { menjawab Ragu-ragu (3) }\end{array}$ & $18 \times 3$ & 54 \\
\hline 4 & $\begin{array}{c}\text { Responden yang } \\
\text { menjawab tidak setuju (2) }\end{array}$ & $12 \times 2$ & 24 \\
\hline 5 & $\begin{array}{c}\text { Responden yang } \\
\text { menjawab sangat tidak } \\
\text { setuju (1) }\end{array}$ & $0 \times 1$ & 0 \\
\hline \multicolumn{3}{|c|}{ Total } & $\mathbf{7 8}$ \\
\hline
\end{tabular}

$\mathbf{Y}=$ Skor tertinggi likert $\mathrm{x}$ jumlah responden $(5 \mathrm{x} 30)=150$.

$\mathbf{X}=$ Skor terendah $\mathrm{x}$ jumlah responden $(1 \times 30)=30$.

Jika, jika total responden terhadap media pembelajaran tersebut adalah hasil nilai yang dihasilkan $=52,00 \%$ Kategori Cukup

Berdasarkan hasil diatas dan berpedoman pada tabel kriteria skala sikap maka diperoleh presentasi motivasi belajar siswa sebesar $52,00 \%$ dan masuk dalam kriteria cukup.

\section{KESIMPULAN}

Berdasarkan hasil pengujian hipotesis dan pembahasan penelitian dapat disimpulkan bahwa:

1. Motivasi belajar pada kelas eksperimen yang menggunkana metode pembelajaran menggunkakan alat bantu media pembelajaran memiliki kategori baik. Hal ini, ditunjukkan melalui hasil jawaban penilaian angket diperoleh presentasi motivasi belajar siswa sebesar $79,09 \%$. 
2. Motivasi belajar pada kelas kontrol yang menggunkana metode pembelajaran konvensional memiliki kategori cukup. Hal ini, ditunjukkan melalui hasil jawaban penilaian angket diperoleh presentasi motivasi belajar siswa sebesar $52,00 \%$.

3. Hasil belajar siswa di SMK Negeri 1 Batudaa pada mata pelajaran jaringan dasar pada kelas eksperimen yang menggunakan alat bantu media pembelajaran memiliki nilai yang sedang. Hal ini ditandai dengan presentasi ketuntasan hasil belajar sebesar $47,92 \%$. Sedangkan pada kelas kontrol (proses pembelajaran konvemsional) memiliki nilai yang rendah, ditandai dengan presentasi ketuntasan hasil belajar sebesar 39,99\%.

\section{SARAN}

Berdasarkan kesimpulan di atas, maka dapat diperoleh saran sebgai berikut:

1. Para guru mata pelajaran jaringan dasar disarankan apabila dalam proses pembelajaran menggunakan media pembelajaran agar siswa tertarik serta tidak merasa jenuh dan bosan pada saat menerima mata pelajaran.

2. Para guru mata pelajaran jaringan dasar disarankan ketika membuat media pembelajaran disesuaikan dengan pokok bahasan yang memerlukan penggambaran pada saat penjelasan.

\section{DAFTAR PUSTAKA}

Aimmah, Tusfiyatul. 2015. Pengaruh Multimedia Interaktif terhadap Motivasi dan Hasil Belajar Siswa Kelas VIII SMP Ali Maksum Kapryak Bantul. http://digilib.uinsuka.ac.id/15804/1/BAB\%20I\%2C\%20V\%2C\%20DAFT AR\%20PUSTAKA.pdf. Diakses pada tanggal 17 juli 2017.

Hardiyanto, widi, dkk. 2012. Pemanfaatan Media Pembelajaran Fisika Berbasis Macromedia Flash 8 Guna Meningkatkakan Motivasi Belajar Siswa Pada Pokok Bahasan Sifat Mekanik Bahan Kelas X Tkj 2 SMK Batik Perbaik Tahun Pelajaran 2011/2012. Radiasi. Vol 1 No 1. http://ejournal.umpwr.ac.id/index.php/radiasi/article/down load/307/331. Diakses pada tanggal 24 oktober 2016.

Hidayah. 2015. Pengembangan Multimedia Pembelajaran Pemrograman Dasar Untuk Kelas X SMK. Jurnal Pendidikan Teknik Informatika. Edisi 4. http://journal.student.uny.ac.id/jurnal/download/54/1101/ 12501/pdf . Diakses pada tanggal 28 oktober 2016.

Junianto, Eko. 2014. Pengaruh Media Pembelajaran Berbasis Komputer Terhadapa Motivasi dan Hasil Belajae Siswa Kelas X pada Mata Pelajaran Menggunakana Alat Ukur Kompetensi Keahlian Teknik Kendaraan Ringan SMK Negeri 3 Yogyakarta.

http://eprints.uny.ac.id/26802/1/Eko\%20Junianto\%20085 04241001.pdf. Diakses pada tanggal 17 Juli 2017.

Mutmainah, Mut'ah. 2014. Pengaruh Motivasi Belajar Siswa pada Bidang StudiSejarah Kebudayaan Islam (SKI) di MTS N 19 Jakarta. http://repository.uinjkt.ac.id/dspace/bitstream/123456789/ 25213/3/MUT\%27AH\%20MUTMAINAH-FITK.pdf.

Diakses pada tanggal 14 Juli 2017.

Putri, Wakhidati Nurrohmah. 2017. Pengaruh Media Pembelajaran Terhadap Belajara Bahasa Arab Siswa Madrasah Tsanawiyah. Lisania: Journal of Arabic Education and Literature. Vol 1 No1. http://lisania.iainsalatiga.ac.id/index.php/lisania/article/do wnload/817/618. Diakses pada tanggal 17 Juli 2017.

Sarofi. 2014. Pengembangan Media Pembelajaran Fisika Interaktif Berbasis Macromedia Flash Pada Materi Listrik Dinamis untuk Siswa Smp/Mts Kelas IX. http://digilib.uin-suka.ac.id/12620/. Diakses pada tanggal 28 November 2016.

Sudjana. 2002. Metode Statistika. Bandung: Tarsito.

Sugiyono. 2016. Metode Penelitian Pendidikan Pendekatan Kuamtitatif, Kulitatif, dan $R \& D$. bandung: alfabeta.

Taharudin. 2012. Pengaruh Penggunaan Macromedia Flash Terhadap Motivasi Dan Prestasi Belajar Mata Diklat Las Busur Manual Di Smk N 2 Pengasih. http://eprints.uny.ac.id/2069/1/TAHARUDIN.pdf.

Diakses pada tanggal 13 oktober 2015.

Toha, Habib, dkk. 2014. Penerapan Model Pembelajaran Berbasis Masalah untuk Meningkatkan Hasil Belajar Siswa TKJ pada Pelajarangan Jaringan Dasar di SMK. E-Journal JJPTE Universitas Pendidikan Ganesha Jurusan S1-Pendidikan Teknik Elektro. Volume 3. http://download.portalgaruda.org/article.php? . Diakses pada tanggal 07 desember 2016.

Utami, Diah Ratna. 2012. Pengembangan Media Pembelajaran Topologi Jaringan Komputer Berbasis Macromedia Flash Professional 8 Untuk Siswa Kelas Xii Multimedia Di Smk Negeri 7 Yogyakarta. http://eprints.uny.ac.id/20106/ . Diakses pada tanggal 28 oktober 2016.

\section{Peningkatan Motivasi Belajar Siswa Menggunakan Macromedia Flash Sebagai Media Pembelajaran Interaktif}

